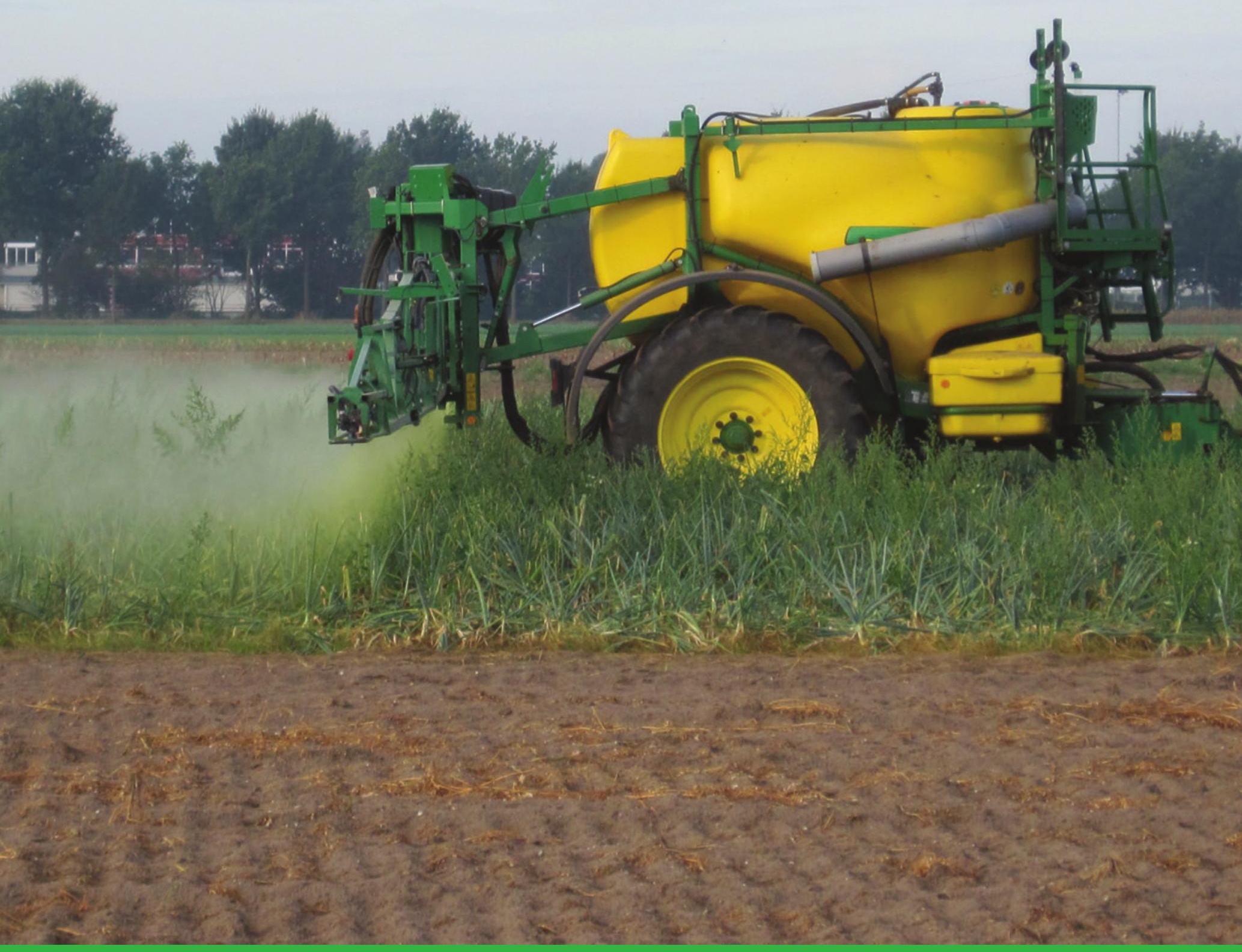

\title{
Spray drift exposure of bystanders and residents when spraying field crops
}





\section{Spray drift exposure of bystanders and residents when spraying field crops}

J.C. van de Zande, J.M.G.P. Michielsen \& H. Stallinga

WR is part of Wageningen University \& Research, the collaboration of Wageningen University and Wageningen Research Foundation.

Wageningen, December 2017

Report WPR-722 
Zande, J.C. van de, J.M.G.P. Michielsen \& H. Stallinga, 2017. Spray drift exposure of bystanders and residents when spraying field crops. Wageningen Research, Report WPR-722. 28 pp.; 6 fig.; 8 tab.; 30 ref.

This report can be downloaded for free at https://doi.org/10.18174/440924

Spray drift can be limited using drift- reducing nozzles and spray techniques and is obligatory when applying Plant Protection Products (PPP) alongside waterways in the Netherlands. The spray drift reducing measures implemented to protect the surface water also protect spray drift exposure of bystanders and residents in the neighbourhood of sprayed field crops using boom sprayers. Spray drift is estimated at different distances from a sprayed field crop based on earlier performed spray drift field experiments. A differentiation is made to measured spray drift deposition at ground level and estimated airborne spray drift up to $50 \mathrm{~m}$ distance from the treated field. Airborne spray drift curves are based on measured airborne spray drift at $5.5 \mathrm{~m}$ distance from the last nozzle. Airborne spray drift is further divided in exposure in the 0-3 $\mathrm{m}$ and 3-6 $\mathrm{m}$ high air layers. Results show that spray drift reducing technology (DRT) is important in reducing the exposure risk of bystanders and residents.

Keywords: spray drift, bystander, resident, agrochemical, boom sprayer, spray drift reduction

(C) 2017 Wageningen, Stichting Wageningen Research, Wageningen Plant Research, Business Unit Agrosystems, P.O. Box 16, 6700 AA Wageningen, The Netherlands; T +31 (0)317 480700 ; www.wur.eu/plant-research

Chamber of Commerce no. 09098104 at Arnhem

VAT NL no. 8065.11.618.B01

Stichting Wageningen Research. All rights reserved. No part of this publication may be reproduced, stored in an automated database, or transmitted, in any form or by any means, whether electronically, mechanically, through photocopying, recording or otherwise, without the prior written consent of the Stichting Wageningen Research.

Stichting Wageningen Research is not liable for any adverse consequences resulting from the use of data from this publication.

\section{Report WPR-722}

Photo cover: Jan van de Zande -Spray drift Reference boom sprayer (Zande-SprayDriftReference_IMG_7776.JPG) 


\section{Contents}

$\begin{array}{ll}\text { Preface } & 5\end{array}$

$\begin{array}{ll}\text { Summary } & 7\end{array}$

$\begin{array}{ll}\text { Samenvatting } & 9\end{array}$

$\begin{array}{llr}1 & \text { Introduction } & 11\end{array}$

$2 \quad$ Material and methods $\quad 12$

$\begin{array}{lll}2.1 & \text { Field measurements of spray drift } & 12\end{array}$

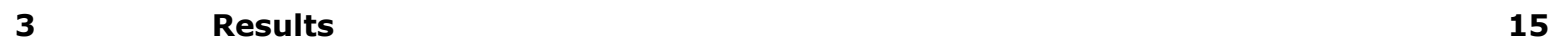

$\begin{array}{lll}3.1 & \text { Field measurements spray drift } & 15\end{array}$

$\begin{array}{lrr}4 & \text { Discussion } & 20\end{array}$

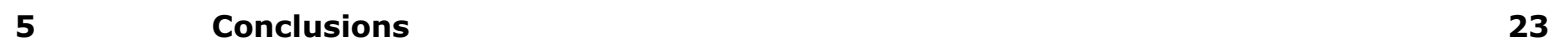

$\begin{array}{ll}\text { References } & 24\end{array}$

Annex 1 Spray drift deposition at ground surface and airborne spray drift 26 



\section{Preface}

Nowadays in many municipalities, discussions are ongoing about the risk of bystanders and residents to spray drift exposure following the application of plant protection products to agricultural fields. In this report, an overview is given on known knowledge from earlier performed spray drift experiments in the Netherlands. Spray drift exposure of ground surface and in the air at different height layers and distances from the edge of the treated field is presented for standard boom sprayer applications and spray drift reducing technologies.

This report is setup as a base inventory of knowledge on spray drift and its potential risk for residents and bystanders at the start of the research project Onderzoek Bestrijdingsmiddelen Omwonenden (OBO).

Wageningen, November 2017 


\section{Summary}

Spray drift, the movement of spray drops during application outside of the treated area because of wind currents, can be limited through the use of drift-reducing nozzles, minimize spray boom height and spray techniques. Spray drift reducing measures are obligatory (Environmental Activities Decree) when applying Plant Protection Products (PPP) alongside waterways in the Netherlands. The spray drift reducing measures implemented to protect the surface water also protect spray drift exposure of bystanders and residents in the neighbourhood of sprayed fields. In Dutch municipalities a discussion is in progress on the building of houses nearby field crops and the exposure of bystanders and residents to plant protection products. In the rural area houses are located within a distance of $50 \mathrm{~m}$ from the fields. Based on jurisprudence in general a safety distance between building and field crops is maintained. The possibility to reduce this safety distance is assessed based on current spray drift knowledge for standard and drift-reducing spray techniques done in earlier spray drift research. Calculations are done with estimations of airborne spray drift differentiated at heights of 0-3 $\mathrm{m}$ and 3-6 $\mathrm{m}$ in the air at 5-50 $\mathrm{m}$ distance from the edge of the crop.

Based on spray drift field measurements spray drift curves are developed for boom sprayer applications. These developed spray drift curves are used to determine the distance to where spray drift deposition at ground surface or at $0-3 \mathrm{~m}$ height in the air meet $1 \%, 0.5 \%$ and $0.1 \%$ spray drift levels. These distances are determined for the standard boom sprayer, a 50\%, 75\%, 90\% and a $95 \%$ spray drift reducing technique (DRT50-DRT95). For the standard spray technique distances are needed of $6.5 \mathrm{~m}, 11.3 \mathrm{~m}$ and $22.6 \mathrm{~m}$ to $1 \%, 0.5 \%$ and $0.1 \%$ spray drift deposition at ground surface. To reach these spray drift levels in the air (0-3 m height) much larger distances are needed, and are estimated at resp. $56 \mathrm{~m}$, more than $75 \mathrm{~m}$ and more than $150 \mathrm{~m}$. For a DRT75 spray technique spray drift deposition at ground surface of $1 \%, 0.5 \%$ and $0.1 \%$ are reached at $1.8 \mathrm{~m}, 3.9 \mathrm{~m}$ and $17.3 \mathrm{~m}$ whereas for airborne spray drift (0-3 m height) these levels are reached at resp. $17 \mathrm{~m}, 31 \mathrm{~m}$ and $63 \mathrm{~m}$. for a DRT95 spray technique the spray drift levels of $1 \%, 0.5 \%$ and $0.1 \%$ are reached for ground deposition at resp. $1.5 \mathrm{~m}, 1.7 \mathrm{~m}$ and $2.6 \mathrm{~m}$ and for airborne spray drift at resp. less than $5 \mathrm{~m}$ (position of measuring pole), less than $5 \mathrm{~m}$ and $14 \mathrm{~m}$. To come to equal levels of spray drift deposition airborne spray drift (0-3 m height) needs a 5 to 10 times larger distance than ground surface spray drift deposition.

Airborne spray drift is relevant for the exposure of bystanders and residents and at $5 \mathrm{~m}$ distance from the treated field 1-4 times higher than spray drift deposition at ground level. At larger distances the ratio airborne/ground deposition of spray drift can be as high as 140 and is dependent on the used spray technique and distance. Whereas DRT can be a solution to minimise spray drift deposition on surface water, it can also be a solution for reducing exposure of bystanders and residents by airborne spray drift. 


\section{Samenvatting}

Drift, het wegwaaien van spuitvloeistof tijdens de bespuiting tot buiten de perceelsgrenzen door wind, kan beperkt worden door op de veldspuit driftbeperkende spuitdoppen te gebruiken, de spuitboomhoogte te beperken of gebruik te maken van bijvoorbeeld luchtondersteuning; één van de maatregelen die vereist is volgens het Activiteitenbesluit Milieubeheer om de drift naar een sloot naast het perceel te beperken. Door deze maatregelen wordt ook de drift op grotere afstand beperkt en de driftblootstelling van omstanders en omwonenden.

Binnen Nederlandse gemeenten doet zich een discussie voor over de bouw van woningen en de blootstelling van omstanders en omwonenden aan gewasbeschermingsmiddelen nabij landbouwpercelen. In het buitengebied komen woningen binnen $50 \mathrm{~m}$ vanaf de perceelgrens van een landbouwperceel voor. Op dit moment wordt naar aanleiding van jurisprudentie generiek een veiligheidsafstand van $50 \mathrm{~m}$ gehanteerd tussen bebouwing en perceelsrand. Om te onderzoeken of het mogelijk is dat deze afstand kritisch is voor de bestemming bewoning is een studie uitgevoerd naar het effect van thans toegelaten standaard en driftarme toedieningstechnieken volgens het Activiteitenbesluit op de driftdepositie naast het perceel op de grond en de drift naar de lucht bij de bespuiting van een veldgewas. Hierbij is gebruik gemaakt van gegevens uit veldonderzoek met een conventionele veldspuit uitgerust met standaard spleetdoppen en spleetdoppen uit de driftreductieklassen $50 \%$ en $75 \%$ driftreductie (DRT50, DRT75), alsook een veldspuit uitgerust met $50 \%$ en $90 \%$ driftreducerende doptypen en het gebruik van luchtondersteuning op de veldspuit (respectievelijk ingedeeld in de $90 \%$ en 95\% driftreductieklassen (DRT90 en DRT95)). Berekeningen zijn uitgevoerd om de drift naar de lucht op 5, 10, 20, 30, 40 en $50 \mathrm{~m}$ afstand van de perceelrand in de lagen 0-3 m en 3-6 m hoogte te kwantificeren.

Op basis van driftonderzoek in het veld met veldspuiten zijn driftcurves ontwikkeld waarmee is bepaald wat de benodigde afstand is om tot $1 \%, 0,5 \%$ en $0,1 \%$ driftpercentage aan depositie op grondoppervlak of over de hoogte 0-3 $\mathrm{m}$ in de lucht te komen voor bespuitingen van een veldgewas met een standaard veldspuit techniek en met $50 \%, 75 \%, 90 \%$ en $95 \%$ driftreducerende spuittechnieken (DRT50-DRT95). Voor de standaard spuittechniek zijn de benodigde afstanden om tot de driftpercentages $1 \%, 0,5 \%$ en $0,1 \%$ te komen voor de drift depositie op de grond resp. 6,5 m, $11,3 \mathrm{~m}$ en 22,6 m van de laatste spuitdop en voor de drift naar de lucht (0-3 m hoog) veel hoger dan $50 \mathrm{~m}$ en is berekend op resp. $56 \mathrm{~m}$, meer dan $75 \mathrm{~m}$ en meer dan $150 \mathrm{~m}$. Voor de DRT75 spuittechniek wordt voor de driftpercentages $1 \%, 0,5 \%$ en $0,1 \%$ voor de driftdepositie op de grond afstanden gemeten van resp. $1,8 \mathrm{~m}, 3,9 \mathrm{~m}$ en $17,3 \mathrm{~m}$ en voor deze driftpercentages naar de lucht (0-3 $\mathrm{m}$ hoog) berekend op resp. $17 \mathrm{~m}, 31 \mathrm{~m}$ en $63 \mathrm{~m}$ van de laatste spuitdop. Voor de DRT95 spuittechniek wordt voor de driftpercentages $1 \%, 0,5 \%$ en $0,1 \%$ voor de driftdepositie op de grond afstanden gemeten van resp. 1,5 m, 1,7 m en 2,6 m en voor deze driftpercentages naar de lucht (0-3 m hoog) berekend op resp. kleiner dan $5 \mathrm{~m}$ (positie van de meetmast), kleiner dan $5 \mathrm{~m}$ en $14 \mathrm{~m}$ van de laatste spuitdop. Om tot een vergelijkbaar driftdepositie percentage in de luchtlaag 0-3 $\mathrm{m}$ hoog te komen is dus een 5 tot 10 keer grotere afstand nodig dan voor hetzelfde driftdepositie percentage op grondoppervlak. Drift naar de lucht is relevant voor de blootstelling van omstanders en omwonenden en op $5 \mathrm{~m}$ afstand van het bespoten perceel 1-4 keer hoger dan de driftdepositie op de grond op dezelfde afstand. Op grotere afstanden zijn luchtdrift/grond verhoudingen van de driftdepositie bepaald tot 140 afhankelijk van de gebruikte spuittechniek en de afstand. Waar DRT een oplossing kan zijn voor het beperken van de driftdepositie op wateroppervlak kan het ook een oplossing zijn om de blootstelling van omstanders en omwonenden van drift door de lucht te beperken. 


\section{Introduction}

In many municipalities in the Netherlands discussions are ongoing about the risk of bystanders and residents to spray drift exposure following the application of plant protection products to agricultural fields. Based on jurisdiction buffer zones of $50 \mathrm{~m}$ between to be treated fields and residents homes are taken into account when new building activities are initiated. When new building activities are planned in the neighbourhood of agricultural fields it is questioned whether this $50 \mathrm{~m}$ buffer zone is sufficiently protective. On the other hand the question is at what distance from treated fields gardens and houses can safely be established based on the exposure of spray drift during boom sprayer applications. Especially taking into account that spray drift reducing techniques can be used as is mandatory done (Environmental Activity Decree; I\&M, 2012) to protect surface water around treated fields and the Sustainable crop protection plan II (EZ, 2013). With spray drift is in this case meant "quantity of plant protection product that is carried out of the sprayed (treated) area by the action of air currents during the application process" (ISO22866). Based in earlier spray drift field measurements quantifying the spray drift reducing effect of different application techniques for field crops (arable, flower bulbs, vegetables) it can be shown what the spray drift deposition at ground surface and what the airborne spray drift is at different distances from the treated crop. Results are presented for a reference boom sprayer application and for different drift reducing technology (DRT) classes. This report provides a basis for what can be expected as spray drift exposure route for plant protection products during spray applications of field crops from the field towards the resident's homes. As such, the report can be used for the definition of known knowledge to prepare new field measurements to quantify exposure of residents as indicated by the Health Council (2014) and RIVM (Bogers et al., 2014). How spray drift is measured and quantified for different spray techniques in spray drift field research is explained in Chapter 2 and results are presented in Chapter 3 for both ground deposition as airborne spray drift. Some results are discussed in Chapter 4 and conclusions are drawn in Chapter 5. 


\section{$2 \quad$ Material and methods}

An inventory is made of spray drift field measurements performed with standard and drift reducing application techniques spraying field crops. Drift reducing techniques were the use of drift reducing nozzle types, end nozzles, stance and sprayer boom height as can be implemented on boom sprayers (De Jong et al., 2000; Michielsen et al., 1999, 2001a, 2001b, 2003; Stallinga et al., 2003a, 2003b, 2003c, 2004a, 2004b). Based on these spray drift measurements with standard (Southcombe et al., 1997) and spray drift reducing nozzle types (VW \& LNV, 2001; Porskamp et al., 1999; TCT, 2015) it is estimated what the reduction in spray drift deposition at 5, 10, 20, 30, 40 and $50 \mathrm{~m}$ from the last nozzle position at the spray boom is. In addition, airborne spray drift at $5.5 \mathrm{~m}$ distance from the last nozzle is presented. Spray drift reduction is presented compared to the spray drift of a reference spray technique. For field crop spraying as a reference a $24 \mathrm{~m}$ working width boom sprayer is used equipped with standard flat fan nozzle types (TeeJet XR11004 at 3 bar spray pressure) applying with a forward speed of $6 \mathrm{~km} / \mathrm{h}$ a spray volume of $300 \mathrm{~L} / \mathrm{ha}$ (Huijsmans et al., 1997). Spray drift reduction is evaluated comparing the spray drift deposition at ground surface of the reference and the candidate spray drift reducing technique at 2-3 m distance from the last nozzle. Spray drift reduction is classified in spray drift reduction technique (DRT) classes of 50\%, 75\%, 90\% and $95 \%$ using representative techniques for each class (Groot et al., 2012; Zande et al., 2012; ISO22369).

Following the Environmental Activity Decree (Activiteitenbesluit Milieubeheer; I\&M, 2012) at the edge of a field with surface water alongside a minimal 50\% DRT must be used on the outside $14 \mathrm{~m}$ of the field in combination with a crop-free buffer zone of $1.50 \mathrm{~m}$ wide when spraying intensively sprayed crops (potatoes, flower bulbs, strawberry, etc.). a crop-free buffer zone is defined as the distance between the last crop row and the top of the bank of the ditch. When using DRT90 or DRT95 application techniques the width of the crop-free buffer zone is allowed to be reduced to $1.0 \mathrm{~m}$ and $0.50 \mathrm{~m}$. For cereals and other crops the minimal crop-free buffer zone is to be $0.50 \mathrm{~m}$ from 2018 onward. Following the implementation of the Sustainable Plant Protection plan (tweede nota duurzame gewasbescherming; EZ, 2013) from 2018 onward, also the minimal requirement for use of DRT is changed to a minimal DRT75 to be used on all fields for the total field area irrespective if there is surface water around the field.

Based on spray drift measurements setup to determine the contribution of multiple spray swathes and the width of a spray free buffer zone to the total spray drift outside of the field (Stallinga et al., 2007) it can be estimated what the spray drift is for standard and spray drift reducing techniques.

Estimations could be done up to larger distances from the edge of field $(50 \mathrm{~m})$ than measured (5 and $15 \mathrm{~m}$ ). A distinction was made between ground deposition of spray drift as well as airborne spray drift.

\subsection{Field measurements of spray drift}

Spray drift field measurements were done to quantify the spray drift reducing capabilities of different spray drift reducing techniques following the specified measurement protocol (CIW, 2003) to certify the techniques in the Netherlands (TCT, 2017). Therefore the outside swath (24 m) of a potato field was sprayed over $75 \mathrm{~m}$ length at the downwind edge of the field. The last nozzle position (outside nozzle at the spray boom) was on average at $10 \mathrm{~cm}$ outside the centre of the last potato row. A schematic presentation of the experimental field is presented in Figure 1. The quantification of the spray drift deposition was done at a bare soil surface area downwind of the treated potato crop. Spray applications were performed with a spray solution of tap water and a fluorescent tracer (Brilliant Sulfo Flavine; BSF, $3 \mathrm{~g} / \mathrm{L}$ ) and a non-ionic surfactant $\left(\right.$ Agral $\left.^{\circledR}, 1 \mathrm{~mL} / \mathrm{L}\right)$ to mimic a standard spray formulation.

Spray drift was quantified as spray deposition on ground surface downwind of the treated area in a double array of collectors laid out at $2 \mathrm{~m}$ distance in a perpendicular direction to the driving direction of the sprayer (and the crop rows). Spray drift collectors (Technofil TF-290; 50x10 cm en 100x10 cm) were with velcro attached to pvc plates. The collectors were positioned $1 \frac{1}{2}-1,1-1 \frac{1}{2}, 1 \frac{1}{2}-2,2-21 \frac{1}{2}$, $2 \frac{1}{2}-3,3-3 \frac{1}{2}, 3 \frac{1}{2}-4,4-4 \frac{1}{2}, 4 \frac{1}{2}-5,5-5 \frac{1}{2}, 5 \frac{1}{2}-6,71 \frac{1}{2}-81 \frac{1}{2}, 10-11$ and $15-16 \mathrm{~m}$ form the last nozzle 
position. During spray application collectors were also placed in the treated area to verify applied spray volume.

Airborne spray drift was measured at $5.5 \mathrm{~m}$ distance from the last nozzle position using a $6 \mathrm{~m}$ high pole at which two vertical lines were attached with ball shaped collectors $(7.5 \mathrm{~cm}$ diameter Siebauer Abtrifftkollektoren art. nr. 00140) positioned at 0, 1, 2, 3, 4, 5 and $6 \mathrm{~m}$ height.

After spraying the collectors were collected and coded for further analysis on the deposited amount of fluorescent tracer. Tank concentration of the tracer was measured on all field measuring days sampling the spray from a spraying nozzle. Blank collectors were analysed to know the background fluorescence of the collectors. In a special test the sensitivity to photolysis (sun degradation) of the batch of BSF tracer was evaluated. In the laboratory the collectors were rinsed with demineralised water and the BSF concentration in the solutions was measured using fluorimetry (Perkin Elmer LS 45). In the same way the blank collectors as the tank concentrations were quantified fluorimetrically.

The measured BSF concentration was calculated as volume of spray collected per unit area of the collector. The percentage of spray drift deposition is presented as the spray drift deposition per unit area on the collectors as percentage of the sprayed volume in the field per unit area.

The spray drift deposition is presented on the areas 41/2-51/2, 91/2-101/2, 191/2-201/2, 291/2-301/2, $391 / 2-401 / 2$ and $491 / 2-501 / 2 \mathrm{~m}$ from the last nozzle. Also the airborne spray drift is presented as the average percentage of airborne spray drift at $5.5 \mathrm{~m}$ distance from the last nozzle.

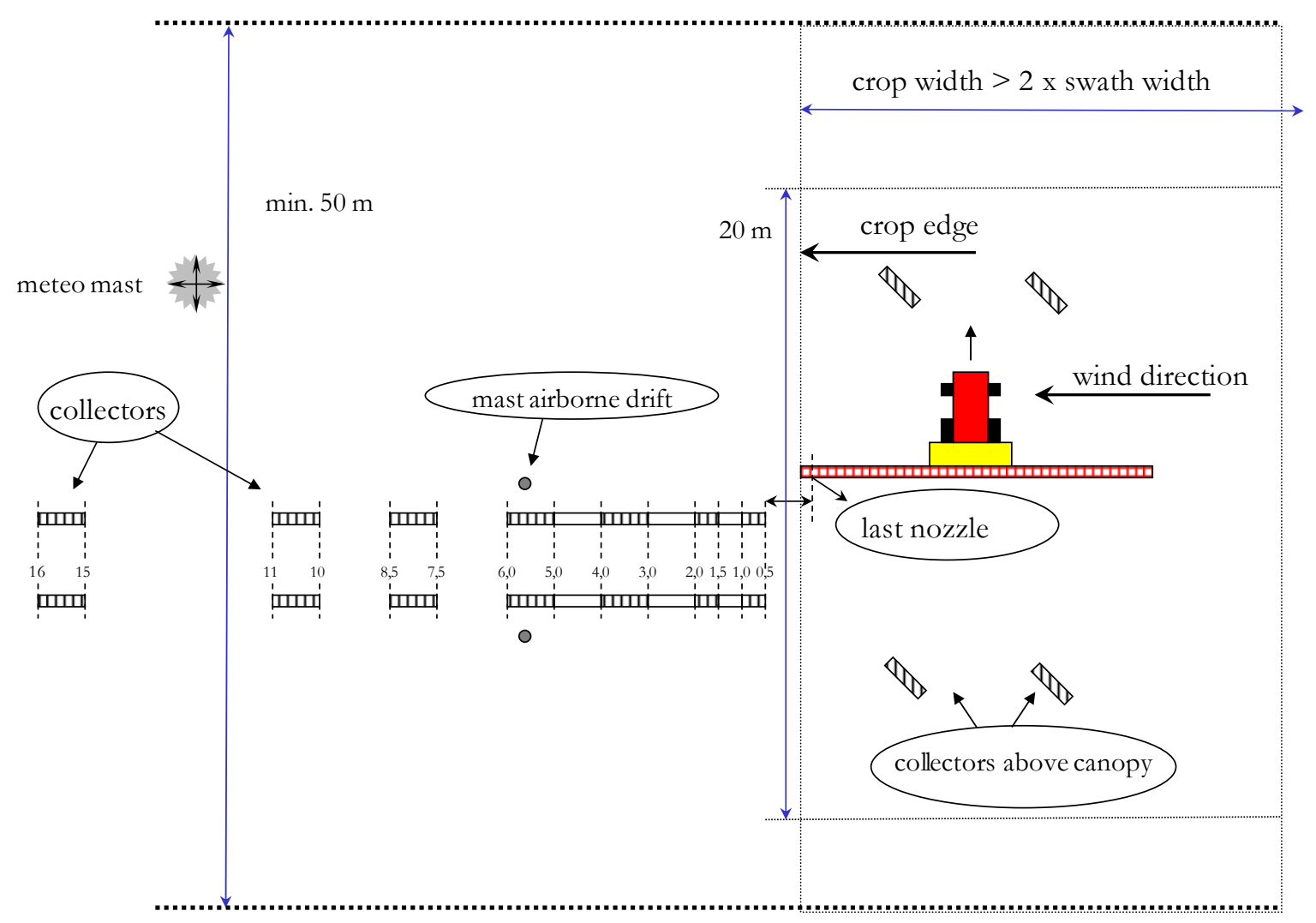

Figure 1 Schematic presentation of the measurement setup and collector layout for field measurements of spray drift in field crops using boom sprayers; right (potato) crop of which a minimal width of $24 \mathrm{~m}$ is sprayed; left, downwind spray drift measurement area, wind blows from right to left.

During the spray drift experiments the weather conditions were recorded in the spray drift measurement area (Figure 1). Weather parameters recorded were temperature (Pt 100 at 0.5 and $2 \mathrm{~m}$ height), air humidity (\%RH, Rhotronic at $0.5 \mathrm{~m}$ height), wind direction $\left(0^{\circ}=\right.$ rectangular to driving direction, at $2.5 \mathrm{~m}$ height) and wind speed (cup-anemometers at 0.5 and $2 \mathrm{~m}$ height) and averaged over time intervals of 5 seconds. The weather conditions during the spray drift experiments 
are presented as the averaged conditions during five time intervals; the time interval the sprayer passed the spray drift ground collectors, two time intervals before and two time intervals after moment of the measurement setup (so in total averaged over 25 seconds). For the wind direction the average was estimated over a time interval of 1 minute before and 1 minute after passing the spray drift measurement setup. Averaged weather conditions during the spray drift experiments are presented in Table 1 for the different spray techniques. Only data are taken into account (Zande et al., 2006; Zande et al., 2012) based on the following restriction of weather conditions:

- Temperature $<25^{\circ} \mathrm{C}$;

- Wind speed, maximal $5.0 \mathrm{~m} / \mathrm{s}$;

- Wind direction, within $+/-30^{\circ}$ to rectangular to the driving direction of the sprayer.

Table 1 Average weather conditions during the spray drift measurements in a potato crop for the different spray techniques as used in this study with the restrictions; temperature $<25^{\circ} \mathrm{C}$, wind speed $<5.0 \mathrm{~m} / \mathrm{s}$ and wind angle $<+/-30^{\circ}$ to rectangular to the driving direction.

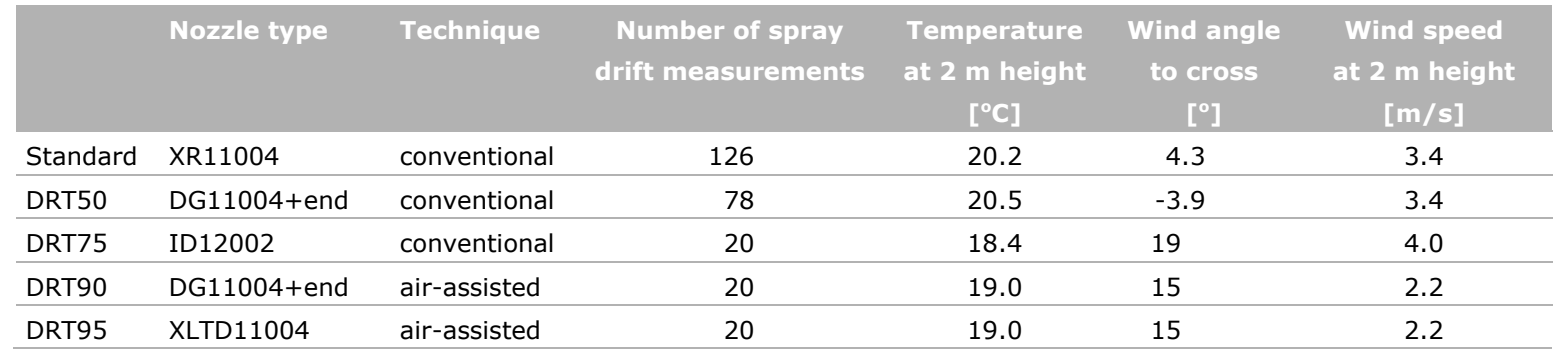

During the spray drift experiments used in this study spraying a potato crop the average wind speed at $2 \mathrm{~m}$ height was $3.4 \mathrm{~m} / \mathrm{s}(1.2-5.0 \mathrm{~m} / \mathrm{s})$ and the average temperature was $20.4{ }^{\circ} \mathrm{C}\left(13.4-25.0{ }^{\circ} \mathrm{C}\right)$. 


\section{Results}

\subsection{Field measurements spray drift}

For downward directed application techniques of Plant Protection Products (PPP) as used in field crops (arable, flower bulbs, vegetables, strawberries, etc.) spray drift reducing techniques can be implemented (Table 2). From experiences in arable crop spraying high levels of spray drift reduction can be obtained. The following spray Drift Reducing Technologies (DRT) in this study are identified and classified in DRT reduction classes (ISO22369). For each DRT class one specific spray technique is identified as representative for its class (Zande et al., 2012), being:

- DRT50; conventional boom sprayer equipped with nozzles from the drift reduction class 50 (DG11004);

- DRT75; conventional boom sprayer equipped with nozzles from the drift reduction class 75 (ID12002);

- DRT90; air-assisted boom sprayer equipped with nozzles from the drift reduction class 50 (DG11004 + air) ;

- DRT95; air-assisted boom sprayer equipped with nozzles from the drift reduction class 90 (XLTD11004 + air).

Table 2 Spray drift reducing techniques and their entry in different Drift Reducing Technology (DRT) classes of downward directed application techniques.

\begin{tabular}{|c|c|}
\hline $\begin{array}{l}\text { Drift } \\
\text { reduction } \\
\text { class }\end{array}$ & iniques in drift reduction class \\
\hline $50 \%$ & $\begin{array}{l}\left.\text { Conventional boom sprayer }+ \text { nozzles drift reduction class } 50^{*}\right) \\
\text { Air-assisted boom sprayer }+ \text { nozzles drift reduction class } 0 \\
\text { Low-boom height }(30 \mathrm{~cm}) \text { conventional boom sprayer }+ \text { nozzle spacing at } 25 \mathrm{~cm}+80^{\circ} \text { nozzles drift reduction } \\
\text { class } 0\end{array}$ \\
\hline $75 \%$ & $\begin{array}{l}\text { Conventional boom sprayer }+ \text { nozzles drift reduction class } 75^{*} \text { ) } \\
\text { Släpduk sprayer / Wingssprayer+ nozzles drift reduction class } 0 \\
\text { Hardi Twin Force air-assisted sprayer }+ \text { nozzles drift reduction class } 0 \\
\text { Hardi Twin Force air-assisted sprayer }+ \text { nozzles drift reduction class } 50+12 \mathrm{~km} / \mathrm{h}\end{array}$ \\
\hline $90 \%$ & $\begin{array}{l}\text { Conventional boom sprayer }+ \text { nozzles drift reduction class } 90 \\
\text { Band sprayer }+ \text { nozzles drift reduction class } 0 \\
\text { Low-boom height }(30 \mathrm{~cm}) \text { conventional boom sprayer }+ \text { nozzle spacing } 25 \mathrm{~cm}+80^{\circ} \text { nozzles drift reduction } \\
\text { class } 50 \\
\text { Low-boom height }(30 \mathrm{~cm}) \text { air-assisted boom sprayer + nozzle spacing } 25 \mathrm{~cm}+80^{\circ} \text { nozzles drift reduction } \\
\text { class } 0 \\
\left.\text { Air-assisted boom sprayer + nozzles drift reduction class } 50^{*}\right)\end{array}$ \\
\hline $95 \%$ & $\begin{array}{l}\text { Conventional boom sprayer }+ \text { nozzles drift reduction class } 95 \\
\left.\text { Air-assisted boom sprayer }+ \text { nozzles drift reduction class } 90^{*}\right) \\
\text { Low-boom height }\left(30 \mathrm{~cm} \text { ) air-assisted boom sprayer }+ \text { nozzle spacing } 25 \mathrm{~cm}+80^{\circ} \text { nozzles drift reduction }\right. \\
\text { class } 50 \\
\text { Hardi Twin Force air-assisted sprayer + nozzles drift reduction class } 50 \\
\text { Släpduk sprayer / Wingssprayer+ nozzles drift reduction class } 50 \\
\text { Tunnel sprayer for bed-grown crops + nozzles drift reduction class } 0\end{array}$ \\
\hline
\end{tabular}

*) This spray technique is representative for its drift reduction class.

Spray drift deposition at ground surface

Spray drift deposition at ground surface is for the downwind area of the treated field crop in Figure 2 presented for the standard and the spray drift reducing techniques of the spray drift reduction classes DRT50, 75, 90 and 95 (Zande et al., 2012). The spray drift reduction is obtained from field spray drift 
measurements in comparison with the defined reference spray technique (Huijsmans et al., 1997) and expressed as the spray drift reduction evaluated at 2-3 m distance from the last nozzle, the area where in a standardised surface water body the surface water is positioned. Spray drift reduction at larger distances is for the DRT50, DRT75, DRT90 and DRT95 classes used in this study based on Groot et al. (2012) and presented in Table 3.

Table 3 Spray drift reduction (\% relative to standard technique equipped with XR11004 flat fan nozzle types) for downward directed spray drift reducing techniques (DRT50, DRT75, DRT90 and DRT95) at different distances from the edge of the field.

\begin{tabular}{|c|c|c|c|c|c|c|}
\hline \multirow[b]{2}{*}{ Spray technique } & \multicolumn{6}{|c|}{ Distance $(\mathrm{m})$} \\
\hline & 5 & 10 & 20 & 30 & 40 & 50 \\
\hline DRT50 & 41 & 42 & 50 & 56 & 62 & 67 \\
\hline DRT90 & 85 & 80 & 66 & 41 & 30 & 0 \\
\hline DRT95 & 95 & 91 & 76 & 38 & 30 & 0 \\
\hline
\end{tabular}

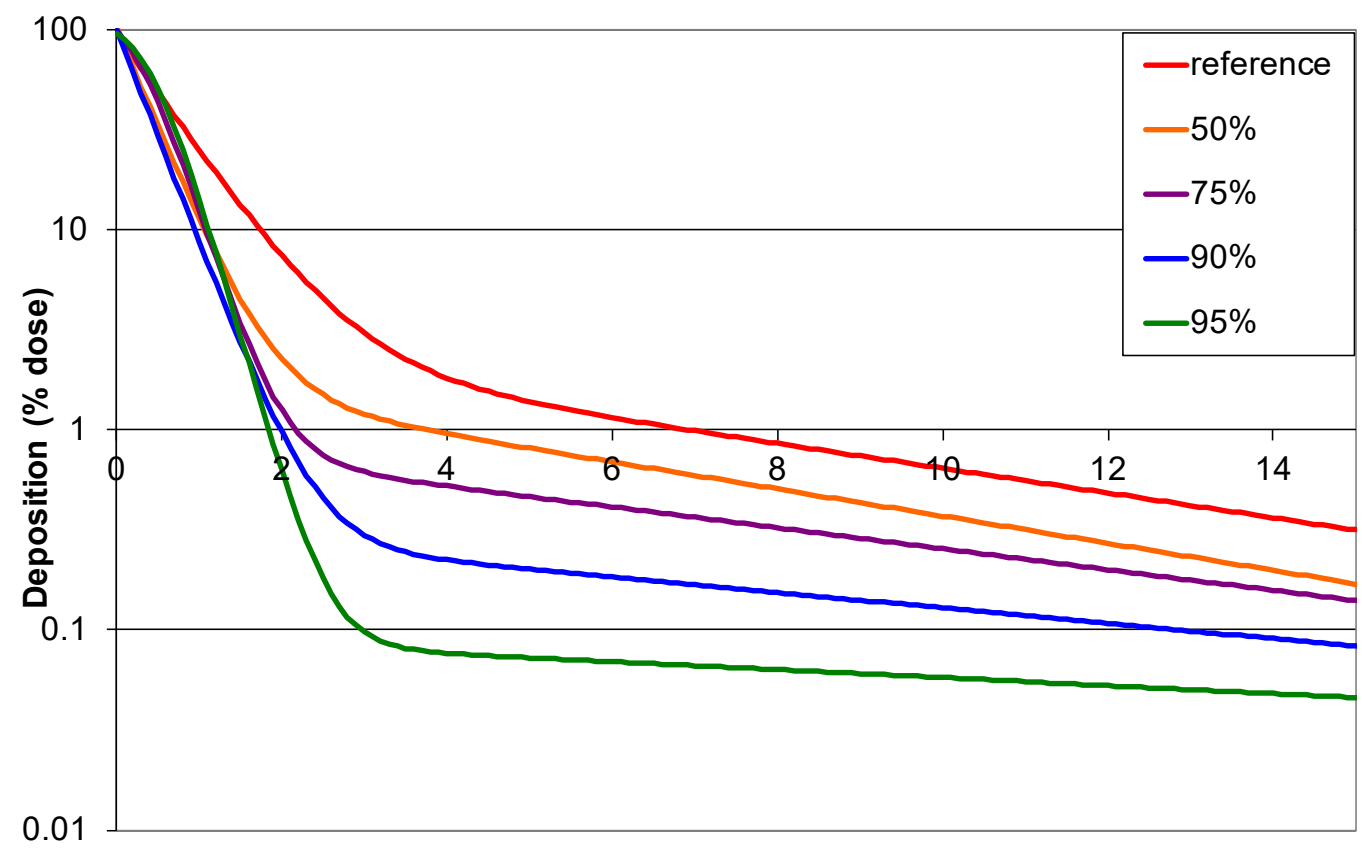

Distance to last nozzle $(\mathrm{m})$

Figure 2 Spray drift deposition (\% of applied spray volume) downwind of a sprayed field crop using a standard (reference) and spray drift reducing techniques in the Drift Reducing Technology (DRT) classes 50\%, 75\%, 90\% and 95\% (after Zande et al., 2012).

With increasing distance from the crop edge spray drift deposition at ground surface decreases. For the standard spray application the spray drift deposition level of $1 \%$ is reached at a distance of $7 \mathrm{~m}$ from the crop edge. For a DRT50 spray technique the same level of spray drift deposition is reached at a distance of $4 \mathrm{~m}$ whereas for the DRT75, DRT90 and DRT95 spray techniques this distance is around $2 \mathrm{~m}$ from the crop edge.

Depending on the choice of spray technique from a DRT class spray drift deposition can be more than $90 \%$ reduced at $10 \mathrm{~m}$ distance from the crop edge (Table 4). At $20 \mathrm{~m}$ distance from the crop edge there is little difference anymore between the spray drift reduction of the different DRT classes (Table 3) and can reduce to 0 at larger distances. The difference in drift reduction capabilities of DRT class techniques at ground surface is especially clear in the first $20 \mathrm{~m}$ from the crop edge. 
Table $4 \quad$ Spray drift deposition at ground surface (\% of sprayed volume) at different distances from the crop edge for a standard boom sprayer application and spray drift reducing techniques of the Drift Reducing Technology classes 50\% (DRT50), 75\% (DRT75), 90\% (DRT90) and 95\% (DRT95) when spraying a field crop.

\begin{tabular}{|c|c|c|c|c|c|}
\hline \multirow[b]{2}{*}{ Distance $[\mathrm{m}]$} & \multicolumn{5}{|c|}{ Spray drift [\% of sprayed volume] } \\
\hline & Standard & DRT50 & DRT75 & DRT90 & DRT95 \\
\hline 5 & 1.26 & 0.75 & 0.44 & 0.19 & 0.07 \\
\hline 20 & 0.14 & 0.07 & 0.07 & 0.05 & 0.04 \\
\hline 30 & 0.03 & 0.02 & 0.02 & 0.02 & 0.02 \\
\hline 50 & 0.00 & 0.00 & 0.00 & 0.00 & 0.00 \\
\hline
\end{tabular}

\section{Airborne spray drift}

During the spray drift field measurements not only spray deposition at ground surface was measured but also how much spray drift is passing at $5 \mathrm{~m}$ distance from the crop edge through the air. Airborne spray drift at $5 \mathrm{~m}$ distance from the crop edge (Figure 3) was when averaged over measuring height of $0-4 \mathrm{~m} \mathrm{3.4 \%}$ of applied spray volume per unit area in the field (Zande et al., 2006, 2012). A DRT50 spray technique reduces airborne spray drift with $35 \%$ at $5 \mathrm{~m}$ distance from the crop edge. Spray drift reducing techniques from the classes DRT75, DRT90 and DRT95 reduce airborne spray drift respectively with $49 \%, 93 \%$ and $94 \%$ at $5 \mathrm{~m}$ distance from the crop edge.

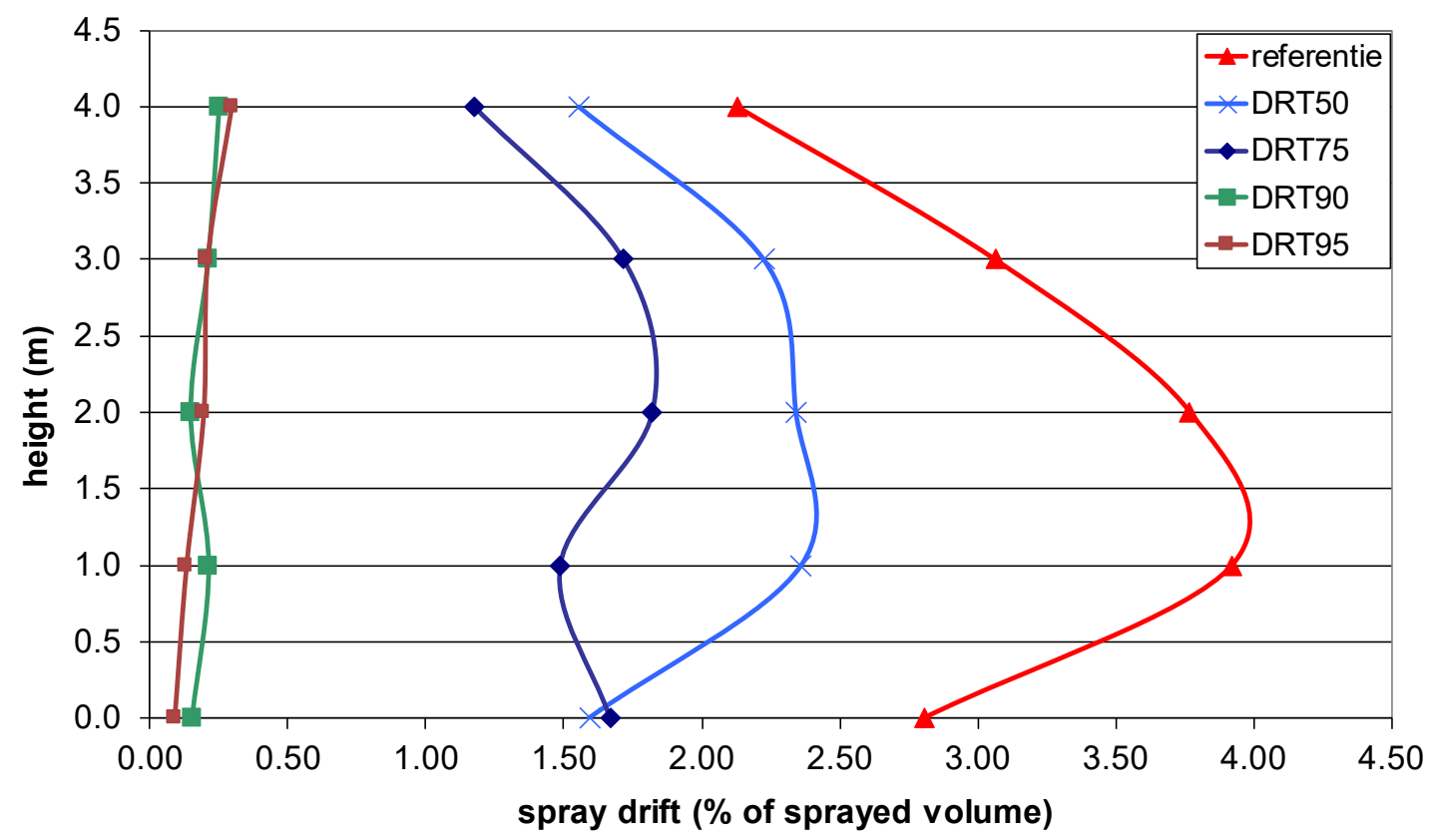

Figure 3 Airborne spray drift (\% of sprayed volume per unit area) at different heights and $5.5 \mathrm{~m}$ distance from the last nozzle for a standard boom sprayer (reference) and spray drift reducing techniques of the Drift Reducing Technology 50\% (DRT50), 75\% (DRT75), 90\% (DRT90) and 95\% (DRT95) spraying a potato crop (after Zande et al., 2006).

Airborne spray drift is not homogeneously distributed over height in the air. Airborne spray drift is higher at sprayer boom height above crop canopy. Spray drift moves with the wind above the field crop to outside the treated field (Figure 4 and Figure 5). The decrease in airborne drift from crop edge to larger distances is different for the different nozzle types (Stallinga et al., 2007). An airborne spray drift level of $1 \%$ spray drift deposition at $2 \mathrm{~m}$ height is reached at $28 \mathrm{~m}$ distance for the standard nozzle type XR11004 whereas for the DG11004 nozzle (DRT50) this is about $15 \mathrm{~m}$. 


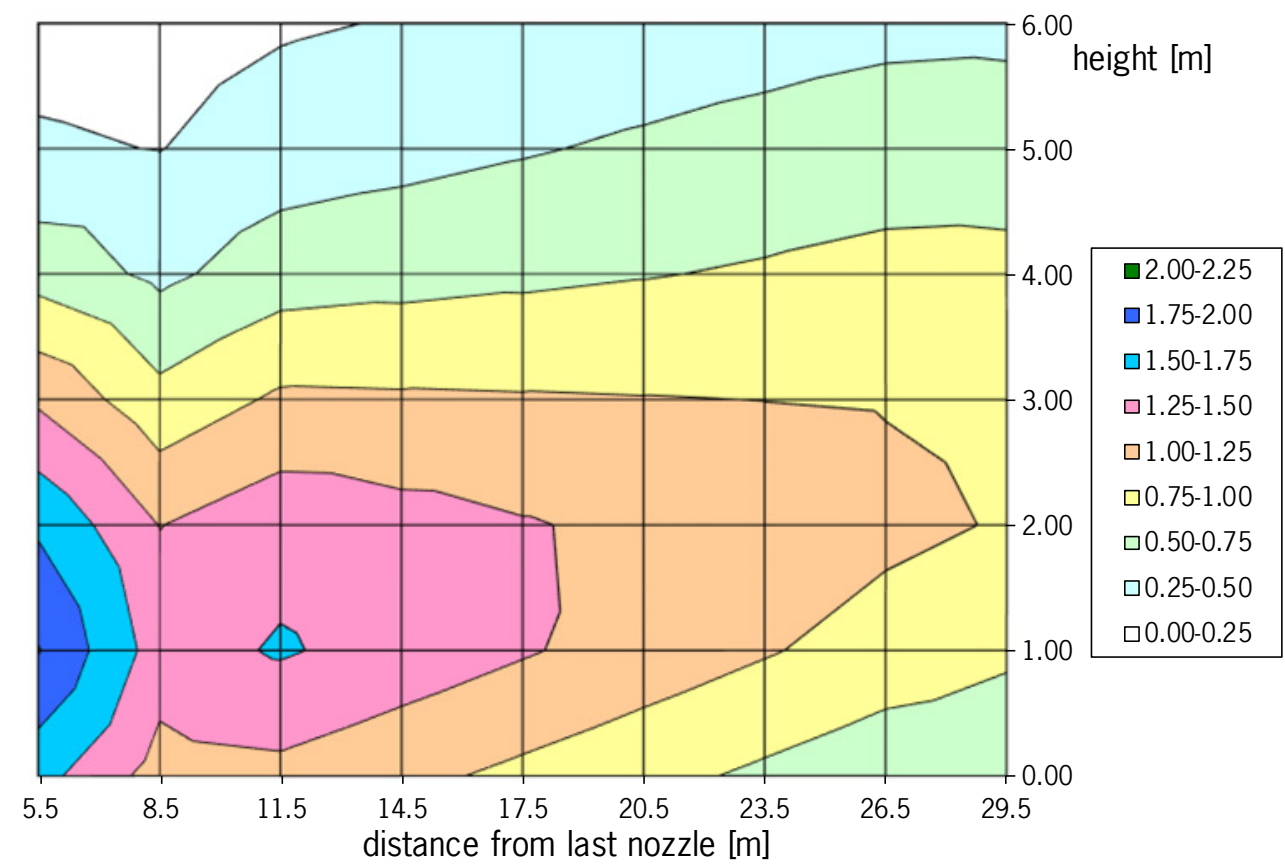

Figure 4 Airborne spray drift (\% of sprayed volume) downwind of a sprayed field crop using a standard boom sprayer equipped with standard flat fan nozzles (300 I/ha; XR11004) (after Stallinga et al., 2007).

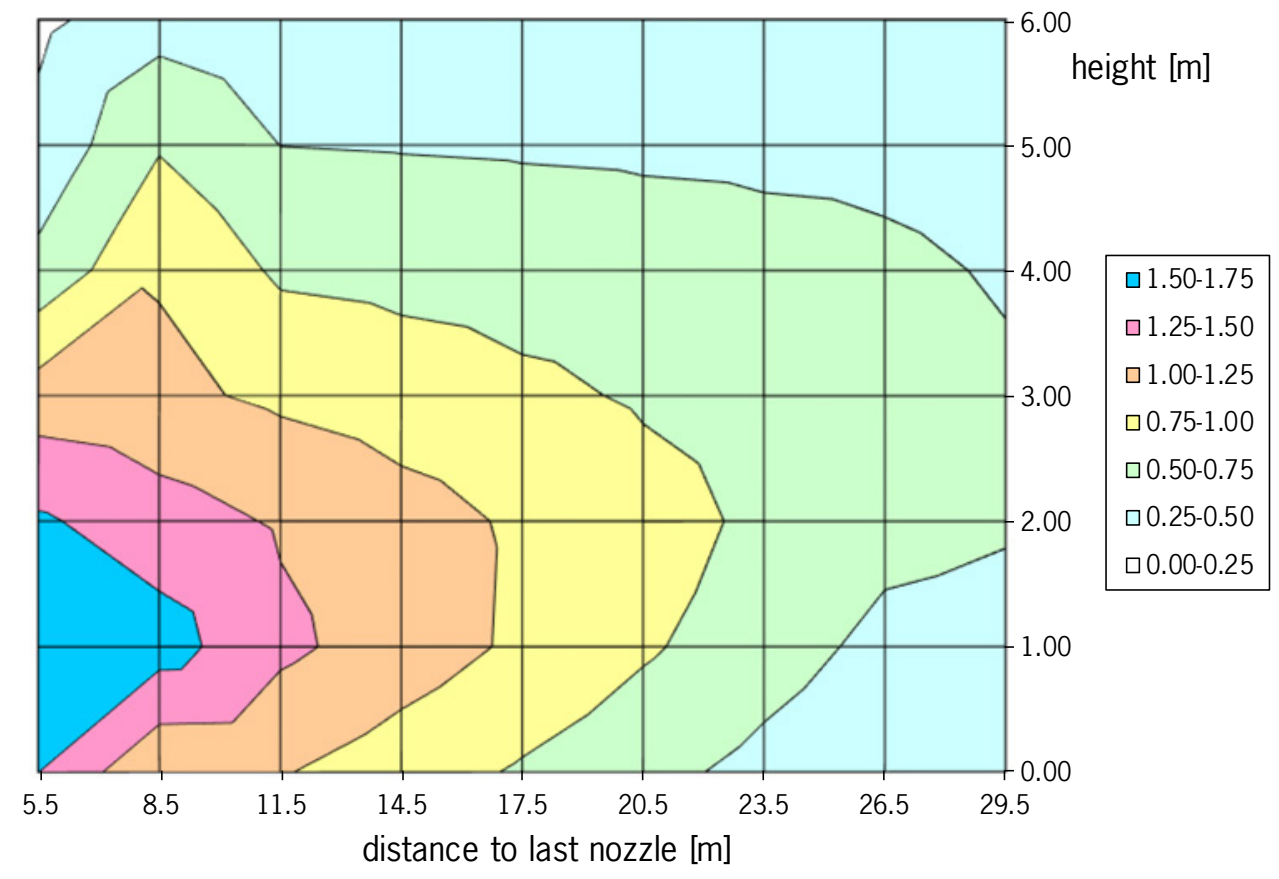

Figure 5 Airborne spray drift (\% of sprayed volume) downwind of a sprayed field crop using a standard boom sprayer equipped with 50\% drift reducing flat fan nozzles (300 I/ha; DG11004; DRT50) (after Stallinga et al., 2007).

The spatial distribution of spray drift in the air of a boom sprayer equipped with a standard flat fan nozzle (XR11004) a driftreducing nozzle (DG11004; DRT50) and both nozzle types in combination with air assistance (Hardi Twin Force) on the boom sprayer were used to estimate the airborne spray drift of the reference spray technique and the DRT50, DRT75, DRT90 and DRT95 techniques. For the standard spray technique the spatial airborne drift distribution of the XR11004 is used. The spatial airborne spray drift distribution of the DG11004 is used for the DRT50 and DRT75 spray techniques. 
For the DRT90 and DRT95 techniques the spatial airborne spray drift distribution of resp. the XR11004 and the DG11004 in combination with the Hardi Twin Force air assistance was used.

Average airborne spray drift of the reference measurements over the period 1998-2005 was used as the basis. From this airborne spray drift deposition curve with height at $5.5 \mathrm{~m}$ from the last nozzle, the airborne spray drift was calculated for the different DRTs, based on their measured airborne spray drift reduction at different heights. With these calculated airborne spray drift distributions for each of the different DRT classes at $5.5 \mathrm{~m}$ from the last nozzle the airborne spray drift distribution with distance and height is estimated based on the spatial distributions indicated. From these calculated distributions the airborne spray drift is presented for the height layers 0-3 m and 3-6 m up to $50 \mathrm{~m}$ distance from the treated crop edge (Table 5). The height layer 0-3 $\mathrm{m}$ can be seen as representing the first floor of a residence and the area where persons can move around. The height 3-6 $\mathrm{m}$ can be seen as representing a second floor height of residents homes.

Table 5 Airborne spray drift (\% of sprayed volume) at 0-3 $m$ and 3-6 $m$ height from ground surface at different distances from the crop edge for a standard boom sprayer application and spray drift reducing techniques of the Drift Reducing Technology classes 50\% (DRT50), 75\% (DRT75), 90\% (DRT90) and 95\% (DRT95) when spraying a field crop.

\begin{tabular}{|c|c|c|c|c|c|c|c|c|c|c|}
\hline \multirow[b]{2}{*}{ Distance [m] } & \multicolumn{5}{|c|}{ Bottom 0-3 m } & \multicolumn{5}{|c|}{ 3-6 $\mathrm{m}$ height } \\
\hline & Standard & DRT50 & DRT75 & DRT90 & DRT95 & Standard & DRT50 & DRT75 & DRT90 & DRT95 \\
\hline 5 & 3.1 & 2.3 & 1.8 & 0.23 & 0.13 & 1.7 & 1.4 & 1.1 & 0.19 & 0.19 \\
\hline 20 & 2.2 & 1.1 & 0.8 & 0.14 & 0.080 & 1.6 & 1.3 & 1.0 & 0.17 & 0.16 \\
\hline 30 & 1.8 & 0.7 & 0.5 & 0.10 & 0.056 & 1.6 & 1.2 & 0.9 & 0.16 & 0.14 \\
\hline 50 & 1.1 & 0.3 & 0.19 & 0.05 & 0.028 & 1.5 & 1.0 & 0.77 & 0.14 & 0.11 \\
\hline
\end{tabular}

With the determined spray drift curves for ground deposition and airborne spray drift over larger distances it can be estimated at what distance e.g. the spray drift levels of $1 \%, 0.5 \%$ and $0.1 \%$ are met. For the standard and the spray drift reducing techniques of the DRT50, DRT75, DRT90 and DRT95 classes these estimated distances are presented in Table 6.

Table 6 Distances $(m)$ to different levels of spray drift deposition (\% of sprayed volume) at ground surface $(m)$ and in the air (averaged over 0-3 $m$ height) when spraying a field crop with a standard boom sprayer and 50\%-95\% spray drift reducing techniques (DRT50-DRT95).

\begin{tabular}{|c|c|c|c|c|c|c|c|c|c|c|}
\hline \multirow[b]{2}{*}{$\%$ drift } & \multicolumn{5}{|c|}{ Spray drift deposition at ground } & \multicolumn{5}{|c|}{ Airborne spray drift at 0-3 $\mathrm{m}$ height } \\
\hline & Standard & DRT50 & DRT75 & DRT90 & DRT95 & Standard & DRT50 & DRT75 & DRT90 & DRT95 \\
\hline $1 \%$ & 6.5 & 3.3 & 1.8 & 1.6 & 1.5 & 56 & 22 & 17 & $<5$ & $<5$ \\
\hline $0,5 \%$ & 11.3 & 7.6 & 3.9 & 2.0 & 1.7 & $>75$ & 36 & 31 & $<5$ & $<5$ \\
\hline $0,1 \%$ & 22.6 & 17.9 & 17.3 & 12.4 & 2.6 & $>150$ & 69 & 63 & 31 & 14 \\
\hline
\end{tabular}

For the standard spray technique the distances to meet the spray drift deposition levels of $1 \%, 0.5 \%$ and $0.1 \%$ are for the spray drift deposition at ground surface resp. $6.5 \mathrm{~m}, 11.3 \mathrm{~m}$ and $22.6 \mathrm{~m}$ from the last nozzle (Table 6). For the airborne spray drift (0-3 m height) these distances are much larger than $50 \mathrm{~m}$ and are calculated as resp. $56 \mathrm{~m}$, more than $75 \mathrm{~m}$ and more than $150 \mathrm{~m}$. The DRT75 spray technique reaches the spray drift deposition levels of $1 \%, 0.5 \%$ and $0.1 \%$ at ground surface at resp. $1.8 \mathrm{~m}, 3.9 \mathrm{~m}$ and $17.3 \mathrm{~m}$ whereas airborne spray drift (0-3 $\mathrm{m}$ height) for these levels for this technique is estimated at resp. $17 \mathrm{~m}, 31 \mathrm{~m}$ and $63 \mathrm{~m}$ distance from the last nozzle. For the DRT95 technique the distances to reach the spray drift deposition levels of $1 \%, 0.5 \%$ and $0.1 \%$ are for the ground deposition estimated at resp. $1.5 \mathrm{~m}, 1.7 \mathrm{~m}$ and $2.6 \mathrm{~m}$. For the airborne spray drift (0-3 m height) these levels are estimated for the DRT95 at resp. less than $5 \mathrm{~m}$ (position of the measurement pole), smaller than $5 \mathrm{~m}$ and $14 \mathrm{~m}$ from the last nozzle. To come to comparable levels of airborne spray drift deposition about 5 to 10 larger distances are needed than for the same level of spray drift deposition at ground surface. 


\section{Discussion}

\section{Spray drift reducing techniques}

When spraying field crops with Plant Protection Products spray drift reducing techniques are used to reduce the emission of PPP to the surface water (Ctgb, 2015; TCT-CIW, 2017). These spray drift reducing techniques are categorised in spray drift reduction classes based on the measured drift reduction at surface water distance of a standardised water body next to the treated field. At larger distances the drift reduction can be different than the one evaluated at surface water distance. The spray drift reducing effects of spray drift reducing nozzle types (50\%, 75\%, 90\%, 95\%), air assistance (standard, Hardi Twin Force), sprayer boom height $(50 \mathrm{~cm}, 30 \mathrm{~cm}$ ) are not all measured up to large distances (most only up to $15 \mathrm{~m}$ from the field edge). The in this study used spray drift deposition curves for ground deposition are based on measured representative techniques for the spray Drift Reduction Technology (DRT) classes 0, 50, 75, 90 and 95 (Groot et al., 2012). From these spray techniques it is known what at $5 \mathrm{~m}$ distance from the crop edge the spray drift to the air is. Only for the standard spray technique (conventional boom sprayer equipped with XR11004 standard flat fan nozzles), the 50\% drift reducing technique (conventional boom sprayer equipped with DG11004 50\% drift reducing flat fan nozzles), and both nozzle types in combination with a Hardi Twin Force air assisted boom sprayer (Stallinga et al., 2007) the spatial distribution of the airborne spray drift is known. The spatial airborne spray drift distribution is estimated based on spray drift measurements with different widths of spray free buffer zones (till $24 \mathrm{~m}$ ) inside a treated crop and a single measuring position ( $5 \mathrm{~m}$ from crop edge) outside the treated field (till $29 \mathrm{~m}$ ). These spatial airborne spray drift distributions are used for the estimation of the airborne spray drift of the different DRT classes as used in this study.

However very limited number of spray drift measurements are done measuring spray drift deposition at larger distances (over $25 \mathrm{~m}$ ). Therefor it is unknown what spray drift reduction at ground surface and especially as airborne spray drift will be at larger distances from the treated crop. It is recommended to perform measurements in future of the spatial distribution of the airborne spray drift and to ground surface up to larger distances (e.g. up to $50 \mathrm{~m}$ ).

\section{Bare soil and crop situation}

The emission from sprayed field crops at the bare soil stage is lower (Figure 6) than when spraying a developed crop canopy (Zande et al., 2012). In this study only the data for the crop situation are presented as indication for a worst case situation.

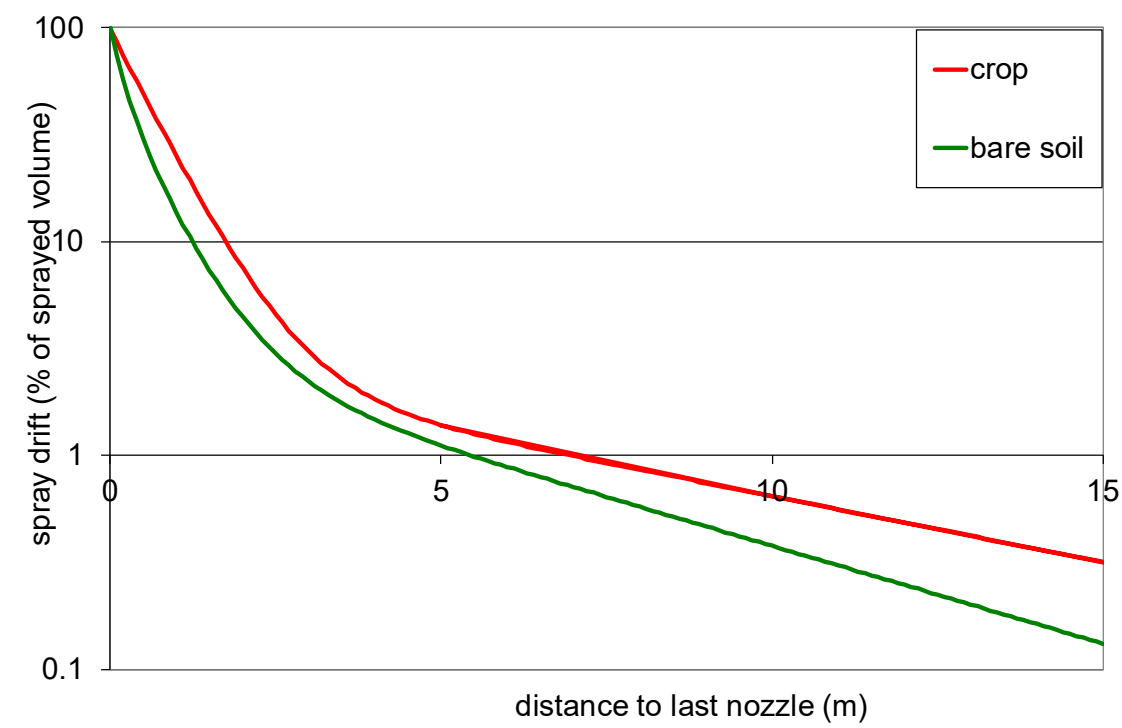

Figure 6 Spray drift deposition downwind of a sprayed field crop using a boom sprayer equipped with standard flat fan nozzles (XR11004) in a cropped and a bare soil situation (after: Zande et al., 2012). 


\section{Barrier crop at edge of field}

Michielsen et al. (2003) investigated the influence of the height of a barrier crop at the edge of the field on spray drift spraying a potato and a sugar beet crop. The strip of barrier crop was mowed at three different heights: equal to crop height, $50 \mathrm{~cm}$ higher than crop height (similar to spray boom height above the crop) and $100 \mathrm{~cm}$ higher than the sprayed crop (total height $150 \mathrm{~cm}$ ). As barrier crop elephants grass (Miscanthus) was planted in two rows (row distance $75 \mathrm{~cm}$ ) at a $2 \mathrm{~m}$ wide strip next to the sprayed field crop. Spray applications were performed with a boom sprayer equipped with XR11004 standard flat fan nozzles at a spray pressure of 3 bar. Also the effect of air assistance on the boom sprayer (Hardi Twin Force) was evaluated. The spray drift reducing effect of the barrier crop was measured downwind behind the barrier crop as spray drift deposition on ground surface and as airborne spray drift on a measuring pole. With increasing height of the barrier crop the spray drift reduction increased. Spray drift reduction to ground surface was not equal for all distances. Close behind the barrier crop spray drift reduction was high (60-90\%) and at larger distances (7.5 m) spray drift reduction was lower. Possibly a changing wind profile because of the barrier crop influences the spray drift deposition pattern on the ground behind the barrier crop.

The combination of a $1.5 \mathrm{~m}$ high barrier crop ( $1 \mathrm{~m}$ above crop height) and the use of an air-assisted boom sprayer resulted in a spray drift reduction to ground surface of $95-99 \%$.

The average spray drift reduction of a barrier crop of $1.5 \mathrm{~m}$ height ( $1 \mathrm{~m}$ above crop height) for airborne spray drift was for the conventional spray boom and the air-assisted boom sprayer about $44 \%$. The combined spray drift reduction of the barrier crop and the air-assisted sprayer was for the $1.5 \mathrm{~m}$ high barrier crop 92\%. This spray drift reduction was only for the bottom $3 \mathrm{~m}$ height from the ground. Above $3 \mathrm{~m}$ height there is no effect of the $1.5 \mathrm{~m}$ high barrier crop on spray drift reduction. A barrier crop of restricted height is therefor also of limited use for the reduction of spray drift for residents and bystanders and boom sprayer applications in field crops.

The additional effect of spray drift reduction of a $1.5 \mathrm{~m}$ high barrier crop at the edge of a treated field is presented in Figure 6 for the standard spray technique and spray drift reducing techniques of the Drift Reduction Technology classes DRT50, DRT75, DRT90 and DRT95 (Table 5).

Table 7 Airborne spray drift (\% of sprayed volume) at 0-3 $\mathrm{m}$ height at different distances from the edge of sprayed field crop for a standard spray technique and spray drift reducing techniques of the Drift Reducing Technology classes DRT50, DRT75, DRT90 and DRT95 for a $1.5 \mathrm{~m}$ high barrier crop at the downwind edge of the treated field.

\begin{tabular}{lcccccc} 
Distance $[\mathrm{m}]$ & & \multicolumn{5}{c}{ Airborne spray drift [\%] } \\
\cline { 3 - 7 } lower & 5 & Standard & DRT50 & DRT75 & DRT90 & 0.1 \\
\hline $0-3 \mathrm{~m}$ & 10 & 1.4 & 1.0 & 0.8 & 0.1 & 0.06 \\
\hline & 20 & 1.2 & 0.8 & 0.6 & 0.06 & 0.05 \\
\hline & 30 & 1.0 & 0.5 & 0.2 & 0.03 & 0.03 \\
\hline & 40 & 0.8 & 0.3 & 0.14 & 0.02 & 0.01 \\
\hline
\end{tabular}

\section{Airborne and ground deposition of spray drift}

From the presented measured ground deposition of spray drift (Table 4) and the estimated airborne spray drift (Table 5) with distance it becomes clear that airborne spray drift is higher than measured as ground deposition at the same distance. The ratio airborne spray drift in the air layer 0-3 $\mathrm{m}$ height and ground deposition of spray drift is calculated for the same distances (Table 8). 
Table 8 Ratio of airborne spray drift at 0-3 $\mathrm{m}$ height and ground deposition of spray drift at the same distance from the edge of a sprayed field crop for a standard spray technique and spray drift reducing techniques of the Drift Reducing Technology classes DRT50, DRT75, DRT90 and DRT95.

\begin{tabular}{|c|c|c|c|c|c|}
\hline Distance [m] & Standard & DRT50 & DRT75 & DRT90 & DRT95 \\
\hline 5 & 2.2 & 3.1 & 3.9 & 1.2 & 1.9 \\
\hline 10 & 4.7 & 5.3 & 5.8 & 1.7 & 1.8 \\
\hline 20 & 16 & 16 & 11 & 2.8 & 2.0 \\
\hline 25 & 29 & 30 & 18 & 4.0 & 2.2 \\
\hline 35 & 80 & 50 & 40 & 9.0 & 4.7 \\
\hline 40 & 140 & 40 & 31 & 7.0 & 4.0 \\
\hline
\end{tabular}

From Table 8 it becomes clear that the ratio airborne (0-3 m height)/ground spray drift deposition at $5 \mathrm{~m}$ distance ranges from 1.2 to 3.9 depending of the used spray technique. At larger distances this ratio increases from 2 to 30 at $25 \mathrm{~m}$ distance and even to 140 at $40 \mathrm{~m}$ distance. 


\section{Conclusions}

When applying plant protection products to a field crop using a boom sprayer depending on weather conditions spray drift can occur. Spray drift can be reduced using spray drift reducing nozzle types, minimise sprayer boom height and use of air assistance on the boom sprayer. Drift reducing measures are mandatory (Environmental Activity Decree) when applying plant protection products alongside surface water next to the treated field. Because of use of the spray drift reducing techniques also spray drift deposition to the ground and airborne spray drift is reduced at larger distances from the treated field.

With the determined spray drift curves for ground deposition and airborne spray drift over larger distances it was estimated at what distance the spray drift levels of $1 \%, 0.5 \%$ and $0.1 \%$ are met for the standard and the spray drift reducing techniques of the DRT50, DRT75, DRT90 and DRT95 classes. For the standard spray technique the distances to meet the spray drift deposition levels of $1 \%, 0.5 \%$ and $0.1 \%$ are for the spray drift deposition at ground surface resp. $6.5 \mathrm{~m}, 11.3 \mathrm{~m}$ and $22.6 \mathrm{~m}$ from the last nozzle. For the airborne spray drift (0-3 m height) these distances are much larger than $50 \mathrm{~m}$ and are calculated as resp. $56 \mathrm{~m}$, more than $75 \mathrm{~m}$ and more than $150 \mathrm{~m}$. The DRT75 spray technique reaches the spray drift deposition levels of $1 \%, 0.5 \%$ and $0.1 \%$ at ground surface at resp. $1.8 \mathrm{~m}, 3.9$ $\mathrm{m}$ and $17.3 \mathrm{~m}$ whereas airborne spray drift (0-3 $\mathrm{m}$ height) for these levels for this technique is estimated at resp. $17 \mathrm{~m}, 31 \mathrm{~m}$ and $63 \mathrm{~m}$ distance from the last nozzle. For the DRT95 technique the distances to reach the spray drift deposition levels of $1 \%, 0.5 \%$ and $0.1 \%$ are for the ground deposition estimated at resp. $1.5 \mathrm{~m}, 1.7 \mathrm{~m}$ and $2.6 \mathrm{~m}$. For the airborne spray drift (0-3 m height) these levels are estimated for the DRT95 at resp. less than $5 \mathrm{~m}$ (position of the measurement pole), smaller than $5 \mathrm{~m}$ and $14 \mathrm{~m}$ from the last nozzle. To come to comparable levels of airborne spray drift deposition about 5 to 10 times larger distances are needed than for the same level of spray drift deposition at ground surface. From the presented measured ground deposition of spray drift and the estimated airborne spray drift with distance it becomes clear that airborne spray drift is higher than measured as ground deposition at the same distance. The ratio airborne (0-3 m height)/ground spray drift deposition at $5 \mathrm{~m}$ distance ranges from 1.2 to 4 depending of the used spray technique. At larger distances this ratio can increase up to even 140 at 40 m distance. 


\section{References}

Bogers, R.P., D. Schram-Bijkerk, J. Devilee, A.B. Knol \& O.R.P. Breugelmans, 2014. Verkenning van mogelijkheden voor onderzoek naar blootstelling aan gewasbeschermingsmiddelen bij omwonenden. RIVM, RIVM rapport 630030002/2014, Bilthoven. 2014. 92 p.

CIW, 2003. Beoordelingsmethodiek emissiereducerende maatregelen Lozingenbesluit open teelt en veehouderij. Commissie Integraal Waterbeheer, Ministerie van Verkeer en Waterstaat, Werkgroep 4 Water en Milieu, Den Haag. 82 pp.

Ctgb, 2013. Evaluation Manual for the Authorisation of Plant protection products and Biocides according to Regulation (EC) No 1107/2009. NL part. Plant protection products. http://www.ctgb.nl/

De Jong, A., J.M.G.P. Michielsen, H. Stallinga \& J.C. van de Zande, 2000. Effect of sprayer boom height on spray drift. Mededelingen Univ. Gent. 65/2b(2000): 919-930.

EZ, 2013. Gezonde Groei, Duurzame Oogst. Tweede nota duurzame gewasbescherming periode 2013 tot 2023. Ministerie van Economische Zaken, Den Haag. 2013. 44 p.

Gezondheidsraad, 2014. Gewasbescherming en omwonenden. Gezondheidsraad, publicatienr. 2014/02, Den Haag. 2014. 194 p.

Groot, T.T., H.J. Holterman \& J.C. van de Zande, 2012. A drift-calculation tool based on spray drift field measurements in field crops. Aspects of Applied Biology 114, International Advances in Pesticide Application, 2012. p. 215-223.

Huijsmans, J.F.M., H.A.J. Porskamp \& J.C. van de Zande, 1997. Drift(beperking) bij de toediening van gewasbeschermingsmiddelen. Evaluatie van de drift van spuitvloeistof bij bespuitingen in de fruitteelt, de volveldsteelten, en de boomteelt (stand van zaken december 1996). IMAG-DLO Rapport 97-04, IMAG, Wageningen. 38 pp.

I\&M, 2012. Activiteitenbesluit Milieubeheer. Staatsblad 2012 441/643

ISO 22866, 2005. Equipment for crop protection - Methods for the field measurement of spray drift. International Standardisation Organisation, Geneva. 2005.

ISO-22369, 2006. Crop protection equipment - Drift classification of spraying equipment. Part 1. Classes. International Organization for Standardization, Geneva.

Michielsen, J.M.G.P., H. Stallinga \& J.C. van de Zande, 1999. Driftreductie door doptype, een kantdop en luchtondersteuning tijdens de bespuiting van aardappelen. I. Veldonderzoek 1998, spuitvolume 300 I/ha. IMAG-DLO Nota P99-111, Instituut voor Milieu- en Agritechniek, Wageningen. 1999. $31 \mathrm{pp}$.

Michielsen, J.M.G.P., H. Stallinga \& J.C. van de Zande, 2001a. Driftreductie door: druppelgroottespectrum van spuitdoppen en luchtondersteuning. Landbouwmechanisatie 52(2001)4: 16-17.

Michielsen, J.M.G.P., H. Stallinga, A. de Jong \& J.C. van de Zande, 2001b. Drift bij twee typen veldspuiten (aanbouw en getrokken) met verschillende werkbreedtes en niveaus van luchtondersteuning. Veldmetingen 1999. Instituut voor Milieu- en Agritechniek, IMAG Nota P200101, Wageningen. 200124 pp.

Michielsen, J.M.G.P., H. Stallinga \& J.C. van de Zande, 2003. Effect van de hoogte van een vanggewas (Miscanthus) op de drift bij bespuiting van akkerbouwgewassen. Instituut voor Milieu- en Agritechniek, IMAG Rapport 2003-17, Wageningen. 2003. 82 pp.

Porskamp, H.A.J., J.C. van de Zande, H.J. Holterman \& J.F.M. Huijsmans, 1999. Opzet van een classificatiesysteem voor spuitdoppen op basis van driftgevoeligheid. IMAG-DLO Rapport 99-02, IMAG, Wageningen. 22 pp.

Southcombe, E.S.E., P.C.H. Miller, H. Ganzelmeier, J.C. van de Zande, A. Miralles \& A.J. Hewitt, 1997. The international (BCPC) spray classification system including a drift potential factor. Proceedings of the Brighton Crop Protection Conference - Weeds, 1997. November 1997, Brighton, UK. P 371-380.

Stallinga, H., J.M.G.P. Michielsen, P. van Velde \& J.C. van de Zande, 2003a. Driftbeperking door spuitboomhoogteverlaging op een veldspuit. Metingen 2002. Instituut voor Milieu- en Agritechniek, IMAG Nota P2003-18, Wageningen. 2003. 34 pp. 
Stallinga, H., J.M.G.P. Michielsen, P. van Velde \& J.C. van de Zande, 2003b. Effect van spoorbreedte en balansverbetering op de drift. Instituut voor Milieu- en Agritechniek, IMAG Nota P2003-25, Wageningen. 2003. 21 pp.

Stallinga, H., J.M.G.P. Michielsen, P. van Velde \& J.C. van de Zande, 2003c. Driftreductie door gebruik van het Släpduksysteem. Wageningen UR - Agrotechnology \& Food Innovations B.V., Report nr 005, Wageningen. 2003. 32 p.

Stallinga, H., J.M.G.P. Michielsen, P. van Velde \& J.C. van de Zande, 2004a. Effect rijsnelheid op de drift. Wageningen UR, Agrotechnology \& Food Innovations, WUR-A\&F Rapport 160, Wageningen. $45 \mathrm{p}$.

Stallinga, H., Zande, J.C. van de, Michielsen, J.M.G.P. \& Velde, P. van, 2004b. Fine nozzles can be used and reduce spray drift; when used at low boom height and smaller nozzle spacing. Aspects of Applied Biology 71, International advances in pesticide application, 2004. 141-148.

Stallinga, H., J.M.G.P. Michielsen, J.C. van de Zande \& P. van Velde, 2007. Drift en driftreductie door breedte spuitvrije zone en driftbeperkende spuittechniek. Wageningen UR, Plant Research International, WUR-PRI Rapport 147, Wageningen. 2007. 50 p.

Stallinga, H., H.J. Holterman, J.M.G.P. Michielsen \& P. van Velde, 2008. A two-year experimental study on airborne drift using active and passive sampling techniques. International Advances in Pesticide Application, Aspects of Applied Biology 84(2008): 1-8.

TCT, 2017. Lijst beoordeelde technieken volgens Beoordelingsmethodiek emissiebeperkende maatregelen. Lozingenbesluit open teelt en veehouderij.

VW, VROM, LNV, VWS \& SZW, 2000. Lozingenbesluit open teelt en veehouderij. Staatsblad 200043. $117 \mathrm{p}$.

VW, VROM \& LNV, 2007. Wijziging van het Lozingenbesluit open teelt en veehouderij en enige andere besluiten (actualisering lozingenvoorschriften). Staatsblad 2007 143. 35 p.

VW \& LNV, 2001. Regeling testmethoden driftarme doppen Lozingenbesluit open teelt en veehouderij. Staatscourant 1 maart 2001, nr. 43. p. 18.

Zande, J.C. van de, H. Stallinga, J.M.G.P. Michielsen \& P. van Velde, 2006. Driftreductie door Hardi Twin Force luchtondersteuning. Wageningen UR, Plant Research International, WUR-PRI Rapport 124, Wageningen. 2006. 20 p.

Zande, J.C. van de, H.J. Holterman \& J.F.M. Huijsmans, 2012. Spray drift for the assessment of exposure of aquatic organisms to plant protection products in the Netherlands. Part 1: Field crops and downward spraying. Wageningen UR, Plant Research International, WUR-PRI Rapport 419, Wageningen. 84 p. 


\section{Annex 1 Spray drift deposition at ground surface and airborne spray drift}

Airborne spray drift (\% of sprayed volume) at different distances from the last nozzle and two height layers $(0-3 \mathrm{~m}, 3-6 \mathrm{~m})$.

\begin{tabular}{|c|c|c|c|c|c|c|}
\hline & \multirow[b]{2}{*}{ Distance $[\mathrm{m}]$} & \multicolumn{5}{|c|}{ Spray drift [\%] } \\
\hline & & Standard & DRT50 & DRT75 & DRT90 & DRT95 \\
\hline \multirow[t]{7}{*}{ bottom 0-3 m } & 5 & 3.1 & 2.3 & 1.8 & 0.23 & 0.13 \\
\hline & 15 & 2.5 & 1.4 & 1.1 & 0.17 & 0.10 \\
\hline & 20 & 2.2 & 1.1 & 0.8 & 0.14 & 0.080 \\
\hline & 30 & 1.8 & 0.7 & 0.5 & 0.10 & 0.056 \\
\hline & 35 & 1.6 & 0.5 & 0.4 & 0.09 & 0.047 \\
\hline & 40 & 1.4 & 0.4 & 0.31 & 0.07 & 0.040 \\
\hline & 45 & 1.3 & 0.3 & 0.24 & 0.06 & 0.033 \\
\hline \multirow{8}{*}{ 3-6 m height } & 15 & 1.7 & 1.3 & 1.0 & 0.18 & 0.16 \\
\hline & 20 & 1.6 & 1.3 & 1.0 & 0.17 & 0.14 \\
\hline & 25 & 1.6 & 1.2 & 0.9 & 0.17 & 0.12 \\
\hline & 30 & 1.6 & 1.2 & 0.9 & 0.16 & 0.20 \\
\hline & 35 & 1.6 & 1.1 & 0.9 & 0.15 & 0.20 \\
\hline & 40 & 1.5 & 1.1 & 0.83 & 0.15 & 0.20 \\
\hline & 45 & 1.5 & 1.1 & 0.80 & 0.14 & 0.20 \\
\hline & 50 & 1.5 & 1.0 & 0.77 & 0.14 & 0.11 \\
\hline
\end{tabular}

Spray drift deposition (\% of sprayed volume) at ground surface downwind of the treated field [m], distance from the last nozzle.

\begin{tabular}{cccccc}
\hline Distance $[\mathrm{m}]$ & Standard & DRT50 & DRT75 drift [\%] & DRT90 & DRT95 \\
\hline 5 & 1.26 & 0.75 & 0.44 & 0.19 & 0.07 \\
\hline 10 & 0.60 & 0.34 & 0.24 & 0.12 & 0.06 \\
\hline 15 & 0.29 & 0.16 & 0.13 & 0.08 & 0.04 \\
\hline 20 & 0.14 & 0.07 & 0.07 & 0.05 & 0.04 \\
\hline 25 & 0.07 & 0.03 & 0.04 & 0.03 & 0.03 \\
\hline 30 & 0.03 & 0.02 & 0.02 & 0.02 & 0.02 \\
\hline 35 & 0.02 & 0.01 & 0.01 & 0.01 & 0.01 \\
\hline 40 & 0.01 & 0.01 & 0.01 & 0.01 & 0.01 \\
\hline 45 & 0.00 & 0.00 & 0.00 & 0.00 & 0.00 \\
\hline 50 & 0.00 & 0.00 & 0.00 & 0.00 & 0.00 \\
\hline
\end{tabular}


Corresponding address for this report:

P.O. Box 16

6700 AA Wageningen

The Netherlands

T +31 (0)317480700

www.wur.eu/plant-research

Report WPR-722
The mission of Wageningen University and Research is "To explore the potential of nature to improve the quality of life". Under the banner Wageningen University \& Research, Wageningen University and the specialised research institutes of the Wageningen Research Foundation have joined forces in contributing to finding solutions to important questions in the domain of healthy food and living environment. With its roughly 30 branches, 5,000 employees and 10,000 students, Wageningen University \& Research is one of the leading organisations in its domain. The unique Wageningen approach lies in its integrated approach to issues and the collaboration between different disciplines. 



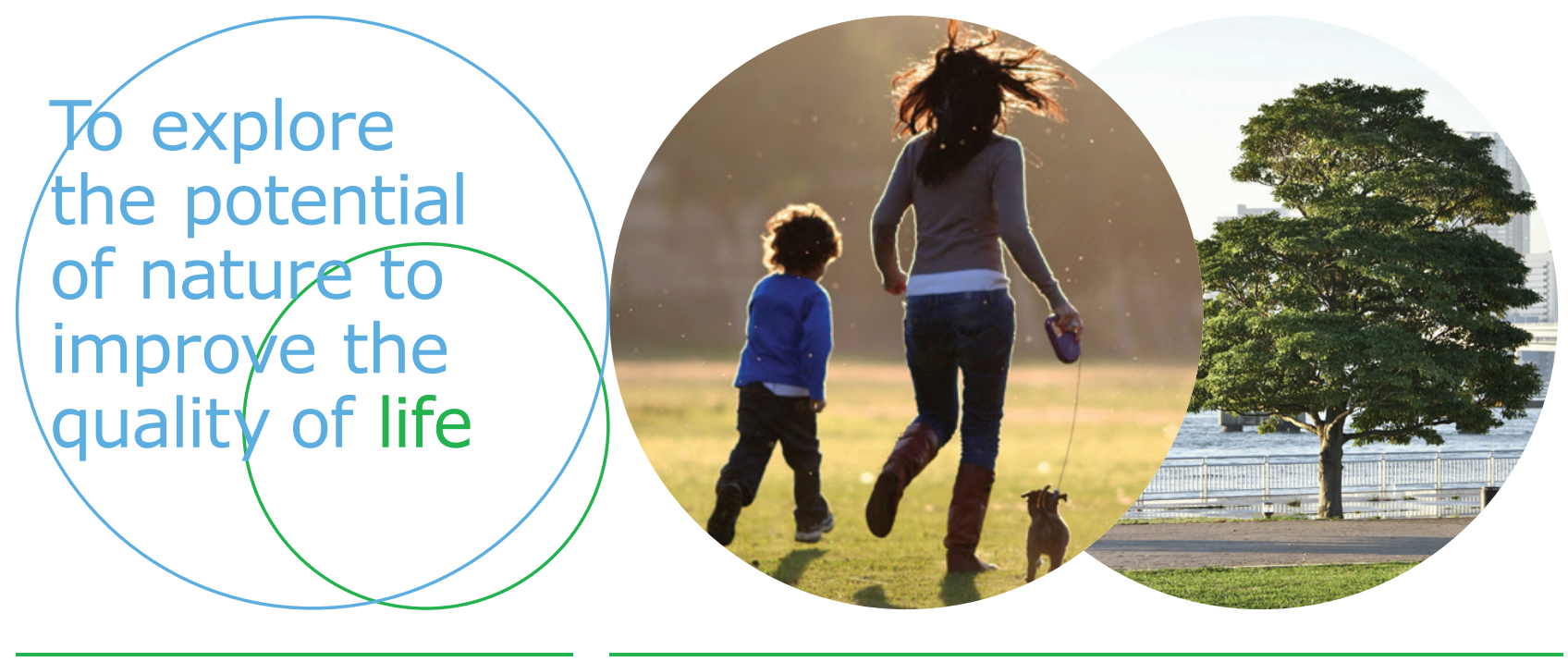

Corresponding address for this report:

P.O. Box 16

6700 AA Wageningen

The Netherlands

T +31 (0)317480700

www.wur.eu/plant-research

Report WPR-722
The mission of Wageningen University and Research is "To explore the potential of nature to improve the quality of life". Under the banner Wageningen University $\&$ Research, Wageningen University and the specialised research institutes of the Wageningen Research Foundation have joined forces in contributing to inding solutions to important questions in the domain of healthy food and living environment. With its roughly 30 branches, 5,000 employees and 10,000 students, Wageningen University \& Research is one of the leading organisations in its domain. The unique Wageningen approach lies in its integrated approach to issues and the collaboration between different disciplines. 